\title{
Alton Stewart Donnelly, 1920-2007
}

Alton S. Donnelly died on 2 January 2007 in Binghamton, New York, after years of declining health. Born in Springville, Utah, on 20 November 1920, Alton grew up in Wyoming. After briefly attending Brigham Young University and the University of Wyoming, he joined the navy with the coming of World War II and trained as a fighter pilot. He served in combat in the Pacific aboard the USS Nehenta Bay, remained active in the Naval Reserve, and was again called to active duty during the Korean War. When he retired from the Naval Reserve, he had attained the rank of captain.

Alton's Russian-language training in the military sparked his lifelong interest in the history of Siberia, the Russian-American Company, and Central Asia. As a graduate student at the University of California, Berkeley, he studied under Raymond Fisher. Selected as one of thirty Americans to participate in the first exchange with the Soviet Union in 1958, he stayed on in 1959 to serve as a guide at the American Exhibition in Moscow. After he returned to the United States, he completed his $\mathrm{PhD}$ at Berkeley in 1960 and then taught at both Northern Illinois University and Fairfield College before relocating to the State University of New York at Binghamton, where he would spend his career.

Alton's first major publication was The Russian Conquest of Bashkiria, 1552-1740: A Case Study in Imperialism (Yale, 1968). This was followed by a series of translations (often with Richard Pierce): S. G. Fedorova's The Russian Population in Alaska and California (1973), R. V. Makarova's Russians on the Pacific, 1743-1799 (1975), and P. A. Tikhmenev's History of the Russian-American Company (2 vols., 1978-1979). Canadian Slavonic Papers published his research on Peter the Great and Central Asia in 1975. In 1985 he returned to translation with T. Tarakanov's The Wreck of the Sv. Nikola. His book on Bashkiria was published in Russia in 1995, and Alton received a gold medal and honorary membership in the Bashkortostan Academy of Sciences.

Always interested in topics few westerners studied, Alton nonetheless found time to devote attention to generations of students. His enthusiasm for his subject was infectious, and his classes were always relaxed but demanding. Ever the scholar and pioneer, even after retirement, Alton was gathering material for a history of Siberia.

The field has indeed suffered a loss with his passing. Alton is survived by his wife and soulmate, Kathleen, who often accompanied him during his lengthy stays in the Soviet Union and the Russian Federation. His warm personality, dedication to his work, and endless curiosity will be greatly missed by his students and colleagues.

\section{Mark Kulikowski \\ State University of New York, Oswego March 2007}

\section{Elliott D. Mossman, 1942-2007}

\author{
Жизнь прожить-не поле перейти.
}

After a long and debilitating illness, Elliott D. Mossman, a former editor of Slavic Review, died in Princeton, New Jersey, on 16 March 2007. Elliott was a major force in the development of Slavic studies at the University of Pennsylvania as a teacher, administrator, and scholar. His editorship of Slavic Review from spring 1992 to spring 1996 left a deep and 
lasting mark on the entire field. Throughout his nearly forty years at Penn, he was a good friend and a wise counselor.

Born in New Rochelle, New York, on 8 November 1942, Elliott was educated at Wesleyan University (BA, 1964) and Princeton University (PhD, 1968) where he worked with Clarence Brown. Elliott then surprised his colleagues in the field by earning a JD degree at the University of Pennsylvania Law School in 1974. The law degree was simply more evidence of his broad range of interests and profound learning. At Penn he served several terms as chair of the department of Slavic languages, transforming it from an undergraduate training ground for students going elsewhere for an advanced degree to a robust research department, maintaining a high reputation for teaching undergraduates while creating a strong doctoral program. From this base he organized and led the scholars at Penn specializing in the Soviet Union and eastern Europe to establish a Center for Soviet and East European Studies under Title VI and then, as director, obtained a $\$ 500,000$ grant from the Andrew W. Mellon Foundation to support the center's research activities. At Penn he also served as associate dean for undergraduate studies and associate dean for planning and development. In all his administrative positions, Elliott exhibited a tolerance, patience, and moral authority than one expects and does not often observe in these capacities.

When he took over the editorship of Slavic Review, he introduced several important innovations. Sensitive to the special needs of scholars in the social sciences for a faster turnaround, he sped up the review process; he also added a section on film reviews, encouraged discussion pieces, and generally enlivened its pages with a variety of formats. His personal contribution took the form of short, elegantly written, and learned essays. No longer than two pages, they were much more than a summary of the main articles. Rather, inspired by the contents of the journal, these pieces reflected his own wide-ranging reading and thinking about issues at the cutting edge of scholarship. They are still worth rereading today.

Elliott was a pioneer in the study of Boris Pasternak's prose and poetry. In collaboration with E. B. and E. V. Pasternak, the poet's son and daughter-in-law, he launched a massive project in 1975 to publish the manuscripts of the novel Doctor Zhivago. At the same time, he began preparing the correspondence between Pasternak and $\mathrm{Ol}^{\prime}$ ga Freidenberg, which he compiled, edited, helped to translate, and introduced in a lengthy commentary. It was published first in English in 1982, with Russian and French editions following in close succession; publication in several other languages came later. Elliott had plans to write a major monograph, "Boris Pasternak: The Poetics of Prose," based upon a complete edition of the correspondence. Unfortunately, he did not live to see this project completed, although parts of it appeared in scholarly journals.

Elliott's interest in the law evolved into a research project on how the social institutions of central planning and the contractual regulation of relationships between juridical persons have interacted historically and continued to do so in the late Soviet period. He taught the substance of this project when he was Ida Beam Distinguished Visiting Professor of Law at the University of Iowa Law School in 1983.

Elliott was widely respected by his colleagues and cherished by his friends; he inspired both loyalty and affection in his students. Elliott is succeeded by his daughter, Ellen, an honors student at Penn, his sister, Marion, and brothers Donald, Dwight, and Garrett.

ALFRED RIEBER
Central European University, Budapest
April 2007

\section{Heinrich A. Stammler, 1912-2006}

Heinrich A. Stammler was born on 15 December 1912, in Jena, Germany. He passed away on 29 November 2006, in Lawrence, Kansas, surrounded by his family: his wife, Ursula Hofmann Stammler; his daughter, Andrea Lewis, and her husband, Patrick; his son, 